\title{
DETECTION OF GENETIC DIVERSITY IN DIFFERENT SOYBEAN (Glycine $\max$ L.) CULTIVARS USING SEED STORAGE PROTEIN PROFILES AND RAPD-PCR ANALYSIS
}

\author{
Mohamed A. Adbel Hamid ", A.E. Mandour, T.A.I. Ismail and A.M. Al-Zohairy \\ Genet. Dept., Fac. Agric., Zagazig Univ., Egypt
}

Received: 07/03/2017 ; Accepted: 18/04/2017

\begin{abstract}
Protein electrophoretic banding patterns of SDS-PAGE and RAPD-PCR analyses were performed to establish molecular diversity pattern for five soybean cultivars (Crawford, Giza 22, Giza 21, Giza 35 and Giza 111) and to elucidate their genetic relationships. The results of protein banding pattern showed a low level of polymorphism, so cannot be used for complete discrimination among the five cultivars under study. However, the results of protein profiles could be considered as indicators for general protein model pattern for the studied soybean cultivars. On the other hand, RAPD-PCR profiles revealed high levels of polymorphism among the five cultivars. Four 10-mer arbitrary primers successfully generated reproducible polymorphic products. Both number and size of the amplified products varied considerably with different primers and a sum of 22 polymorphic and 9 monomorphic bands were generated in all cultivars that used. A total of 8 unique bands were also identified. Two of the primers were more successful in cultivar's identification since they produced unique bands that are characteristics of each cultivar under study. The combination of all polymorphic bands generated by the four primers, were enough to discriminate between the examined soybean cultivars. Various combinations of the three RAPD decamer oligonucleotides had been used in the single-primer to increase the potential of the PCR reaction. To elucidate the genetic relationship, a dendrogram was constructed using both SDS-PAGE and RAPD profiles. The resulting dendrogram revealed three main genetic clusters; the first cluster include Giza22, Crawford and Giza35, while the second cluster, comprised the cultivar Giza21, and the third cluster comprised the cultivar Giza111. The first group has been subdivided into two subgroups; the first subgroup comprised one cultivar (Giza35) whereas the second subgroup included the two cultivars Giza22 and Crawford.
\end{abstract}

Key words: Soybean, Glycine max L., SDS-PAGE, RAPD-PCR.

\section{INTRODUCTION}

Soybean (Glycine max L.) is an important oil and protein crop in Egypt. Soybean contains about $18-24 \%$ oil and $30-50 \%$ protein with considerable amounts of essential amino acids, especially lysine as well as phosphorous, calcium and vitamins. Soybean is one of the most economic and nutritious crop as it has high content of protein and oil (Yaklich et al., 2002). Analysis of genetic variation in crop gene pools is a powerful tool for investigating the origin and early evolution of crop lineages and also have the potential to identify unique genetic resources for continued crop improvement (Badr, 2008). Characterization of the genetic variation in the available germplasm is important for further improvement of crop yield and to impart resistance to biotic and abiotic stresses (Kour and Singh 2004). Morphological markers were not quite enough to expose the genetic diversity between the morphological overlap of cultivars and the morphologically identical accessions (Gardiner and Forde, 1988). The electrophoretic banding patterns of total seed protein as revealed by polyacrylamide gel

* Corresponding author: Tel. : +201064553121

E-mail address: mohamedabdelsalam@yahoo.com 
electrophoresis in the presence of sodium dodecyl sulphate-polyacrylamide gel electrophoresis (SDS-PAGE) has been used for identification and differentiation of large number of crops (Abdelsalam et al., 1998; Aly et al., 2000; Badr et al., 2000; Hassan $2001 \mathrm{a}$ and b). Also, SDSPAGE was used to identify soybean cultivars and to discriminate high yielding soybean plants (Larsen, 1967; Lowry et al., 1974; Mori et al., 1981; Gorman, 1988; Abdel-Tawab et al., 1993; Stejskal and Griga, 1995; Rashed et al., 1997; Hsieh et al., 2001; Fahmy and Salama, 2002). The major limitation for using biochemical techniques is the existence of insufficient polymorphism among closely related cultivars.

Molecular markers have been proven to be powerful tools for assessing genetic variation within and among population of plants. At present, number of PCR based molecular techniques are available for assessing genetic diversity in plants. These include identification of amplified fragment length polymorphism (AFLP), random amplified polymorphic DNA (RAPD) and simple sequence repeats (SSRs). Genetic analysis with RAPD is fast, less technical, less expensive and involves no radioactivity and hybridization. RAPD technique requires small amount of DNA, easy to perform and reveals dominant molecular markers of ultimate potentialities in several fields of plant science including systematics and evolution (Witkus et al., 1994). RAPD markers can be used in genetic diversity, cultivar identification and genetic relationships in soybean (Mienie et al., 1995; Thompson et al., 1998; Chowdhery et al., 2001; Baranek et al., 2002; Barakat, 2004) and other different plants and populations (Al-Khalifa et al., 2005; Bhutta et al., 2006; El-Shazly and El-Metairi, 2006; Lin et al., 2009; Badr et al., 2012; Hoque and Hasan, 2012; Prasanthi et al., 2012). The RAPD method also provides useful evidence for gene mapping (Barua et al., 1993 ; Liu et al., 2000). To increase the potential of the original RAPD assay to generate polymorphic DNA markers with a given set of primers was further increased by combining two primers in a single PCR (Klein-Lank et al., 1991) and using combining three primers (Triple RAPD-PCR) in a single PCR to generate polymorphic DNA in mango (Mansour et al., 2008).
In this study, SDS-PAGE and RAPD-PCR fingerprinting were used to assess the genetic variation among the studied five soybean cultivars and to determine the genetic relationship among studied cultivars.

\section{MATERIALS AND METHODS}

This study was carried out in Molecular Genetics Lab., Microbial Genetics Lab., Biochemical Genetics Lab., Genetics Dept., Biochemistry and Microbiology Departments Labs, Central Lab., Faculty of Agric. Biotechnology Lab., Faculty of Veterinary Medicine, Zagazig University.

\section{Materials}

\section{Seed samples}

Five cultivars of soybean seeds (Glycine max L.) were used in this investigation namely; Giza 21, Giza 22, Giza 35, Giza 111 and Crawford. Seed samples under study were obtained from the Leguminous Crops Department Research (LCDR), Field Crops Research Institute, Agricultural Research Center, Ministry of Agriculture, Giza, Egypt.

Seeds were grown in pots and DNA was extracted from leaves at age of twenty days.

\section{Protein analysis}

Characterization of proteins profiles was carried out using one dimensional sodium dodecyl sulphate-polyacrylamide gel electrophoresis (SDSPAGE). Polyacrylamide slab gel $(12 \%)$ was prepared according to Laemmeli (1970). For each soybean cultivar, ten dry seeds were milled together to a fine powder. Then $0.2 \mathrm{ml}$ of sample buffer $(0.2 \mathrm{M}$ Tris- $\mathrm{HCl} \mathrm{pH} 6.8,2 \%$ SDS) was added to $0.02 \mathrm{~g}$ of seeds meal of each cultivar and stored overnight at $4{ }^{\circ} \mathrm{C}$. Centrifugation was performed at $9000 \mathrm{rpm}$ for 6 minutes and supernatant was collected for analysis. Protein samples were prepared by mixing clear supernatant with sample buffer $(0.125 \mathrm{M}$ Tris$\mathrm{HCl}, \mathrm{pH} 6.8 ; 10 \%$ SDS; $10 \%$ sucrose and $0.1 \%$ mercaptoethanol) in 1:1 ratio and denatured by heating at $90^{\circ} \mathrm{C}$ for 3 minutes. Equal amount of three replicates of each sample was loaded on the gel and electrophoresis was carried out at 15 $\mathrm{mA}$ for about half an hour, and then at $25 \mathrm{~mA}$ 
for 4-6 hr. Molecular weights of different bands were calibrated with Sigma wide range molecular weight marker. Protein bands were visualized by staining the gel using $0.25 \%$ Coomassie Brilliant blue (R-250).

\section{RAPD-PCR Analysis}

\section{DNA isolation}

Freshly excised leaves from ten randomly chosen plants were harvested and mixed together for each cultivar. DNA was isolated from $50 \mathrm{mg}$ of leaf material using DNA extraction kit (Qiagen) (by spectrophotometeric readings at 260 and $280 \mathrm{~nm}$. The 260 to 280 ratios were between 1.7 to 1.8 depicting high purity of the isolated DNAs). The concentration and purity of the extracted DNA was determined. Concentration was adjusted at $6 \mathrm{ng}$ for all samples using TE buffer $\mathrm{pH}$ 8.0.

\section{RAPD-PCR technique}

Four primers 10-bp oligonucleotide of random sequences (Amersham Pharmacia Biotch., USA) were used in the PCR reaction according to Williams et al. (1990). The sequences of these primers are: Primer. 1- CS44 (5' ATTCGGCCG C 3'). Primer No. 2 CS-46 (5' GgGatCTAG C3') ; Primer No3 CS-56 ( 5' TGGTGGGTC C 3 '); Primer No 4 OH-04 (5'GGAAGTCGC C 3').

\section{Triple RAPD-PCR}

To increase the potential of the PCR reaction, various combination of the three decamer oligonucleotides (Primer. 1-CS-44 (5' ATTCGG CCG C 3'). Primer No. 2 CS-46 (5' GGGATCT AG C3'); Primer No3 CS-56 (5' TGGTGGGTC C 3') had been used in the single-primer PCR as suggested by Mansour et al. (2008). Amplification was performed in $25 \mu \mathrm{l}$ total volume containing thirty ng $(5 \mu \mathrm{l})$ from extracted DNA and 5 microliter of each primer. The polymerase chain reaction mixture, PCR kits manufactured by Amersham Pharmacia Biotch. USA, containing all of the necessary reagents was used. The amplification protocol was carried out as follows using PCR unit II biometra; denaturation at $94^{\circ} \mathrm{C}$ for $5 \mathrm{~min} ; 45$ cycle each consists of the following steps: denaturation at $95^{\circ} \mathrm{C}$ for $1 \mathrm{~min}$, annealing at $36^{\circ} \mathrm{C}$ for $1 \mathrm{~min}$; extension at $72^{\circ} \mathrm{C}$ for $2 \mathrm{~min}$; final extension at $72^{\circ} \mathrm{C}$ for $5 \mathrm{~min}$; and hold at $4^{\circ} \mathrm{C}$ until separation on agarose gel and statistical analysis.

\section{Analysis of amplified PCR products}

Amplified PCR products were separated on $1 \%$ agarose gel containing ethedium bromide $(0.5 \mu \mathrm{g} / \mathrm{ml})$ at constant voltage $75 \mathrm{~V}$. After electrophoresis, the RAPD patterns were visualized with UV transilluminator. RAPD markers were scored as DNA fragments present or absent. The band size was estimated by comparison to a standard molecular DNA marker (Promega). The bands scored from SDSprotein and RAPD-PCR analysis were pooled together to construct dendrogram tree using NTsys (Numerical Taxonomy System Program) by Rohlf (1993). The concentration and purity of the extracted DNA was determined. Concentration was adjusted at $6 \mathrm{ng}$ for all samples using TE buffer $\mathrm{pH}$ 8.0. The DNA extracted from each cultivar was used for PCR amplification using PCR unit II biometra according to Williams et al. (1990).

\section{RESULTS AND DISCUSSION}

\section{SDS-PAGE of Seed Storage Proteins}

In soybean, there are a lot of seed storage proteins such as glycinin (11S) and $\beta$-conglycinin (7S), and the $11 \mathrm{~S}$ to $7 \mathrm{~S}$ ratio (Saio and Watanabe, 1969) Protein profile using SDSPAGE of the studied soybean cultivars detected 10 bands with molecular weights approximately ranged from 305 to $15 \mathrm{KDa}$ (Fig. 2) with $40 \%$ polymorphism. Number of total protein bands ranged from 9 bands for Crawford, 8 bands for Giza 111, 8 bands for Giza 35, 7 bands for Giza 22 and 8 bands for Giza 21. The cultivar Crawford has one positive unique band at molecular weight of about $20 \mathrm{KDa}$ (Table 2). Also one positive band was unique to cultivar Giza 35 with molecular weight of about $30 \mathrm{KDa}$.

The SDS-PAGE profiles of the five cultivars of soybean detected 10 bands with $40 \%$ polymorphism. Barakat (2004) reported low level of protein polymorphism among the six cultivars of soybean and five major bands were identified (72, 36, 3220 and $16 \mathrm{KDa}$ ) from 25 detected bands. However Malik et al. (2009) detected 26 bands with $50 \%$ polymorphism 
Adbel Hamid, et al.

Table 1. Name, origin and pedigree of the studied cultivars soybean

\begin{tabular}{lll}
\hline Accession & Origin & Pedigree \\
\hline Giza 21 & Egypt & Crawford $\times$ Celest \\
Giza 22 & Egypt & Crawford $\times$ Forrst \\
Giza 35 & Egypt & Crawford $\times$ Celest \\
Giza 111 & Egypt & Crawford $\times$ Celest \\
Crawford & USA & Williams $\times$ Colombus \\
\hline
\end{tabular}
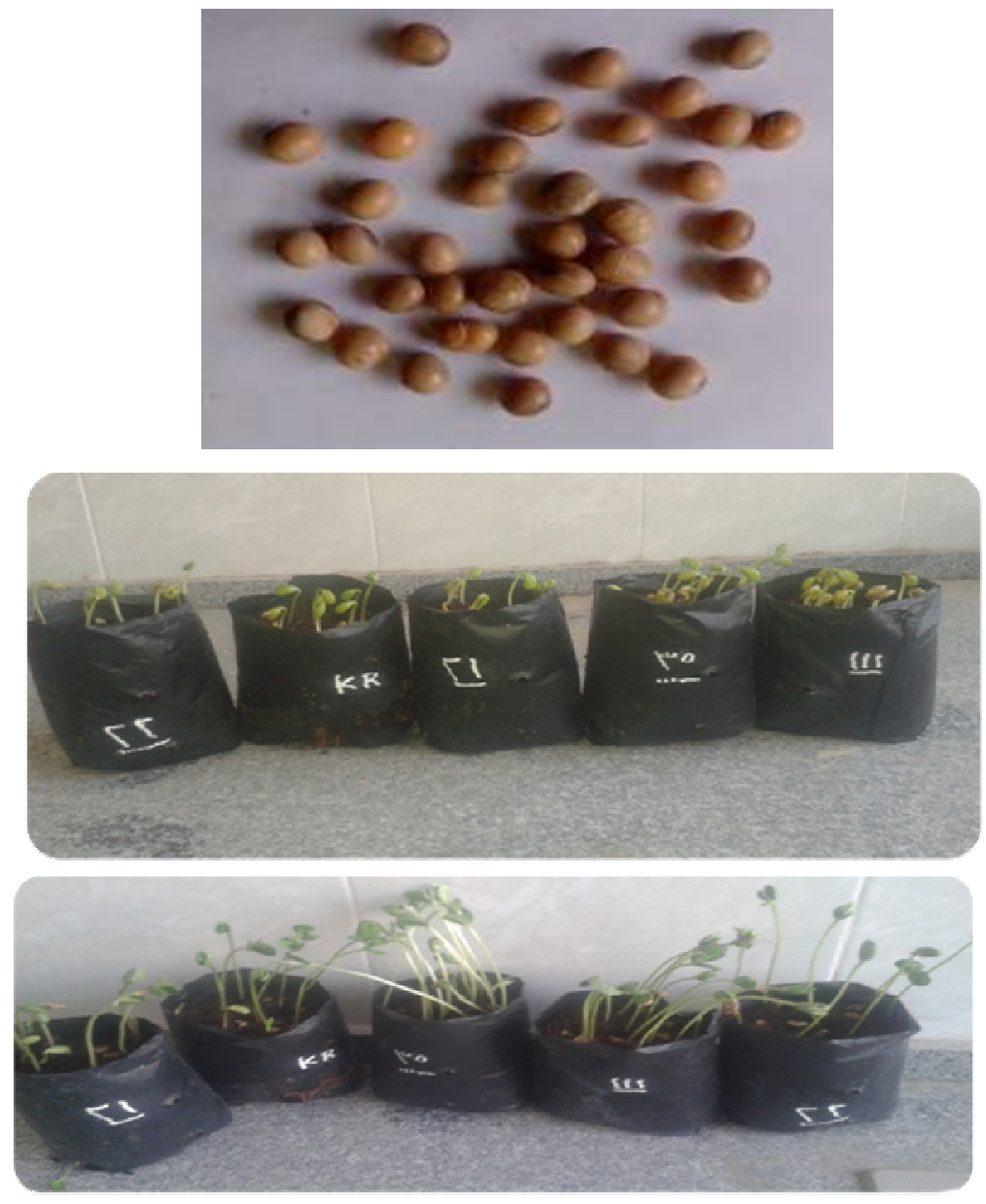

Fig 1: Seeds and seedlings of soybean 
Zagazig J. Agric. Res., Vol. 44 No. (3) 2017

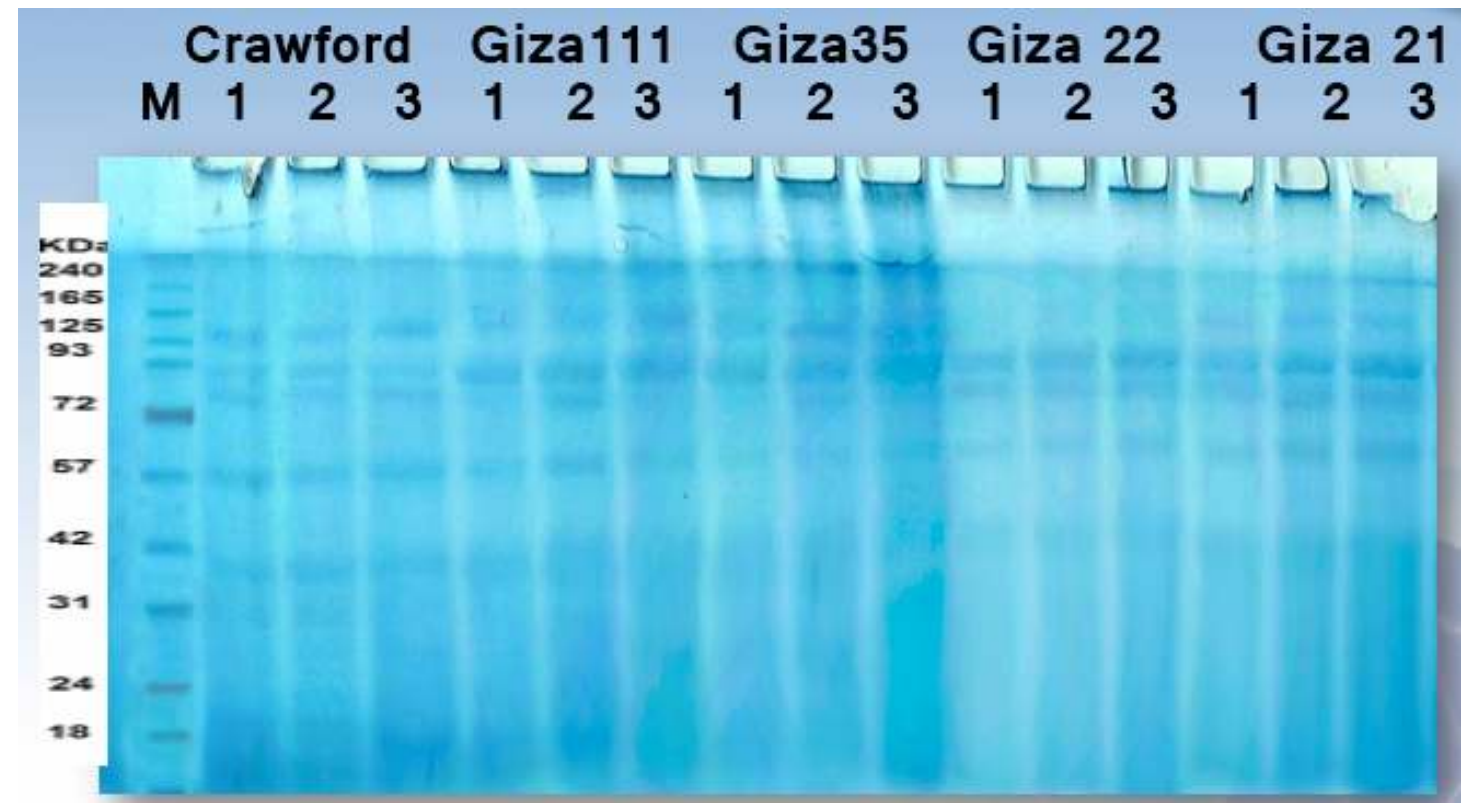

Fig. 2. SDS-PAGE of five cultivars of Soybean

Table 2. Presence and absence of SDS-PAGE protein bands of the studied five soybean cultivars

\begin{tabular}{|c|c|c|c|c|c|c|c|c|c|c|c|c|c|c|c|c|}
\hline & & \multicolumn{3}{|c|}{ Crawford } & \multicolumn{3}{|c|}{ Giza 111} & \multicolumn{3}{|c|}{ Giza 35} & \multicolumn{3}{|c|}{ Giza 22} & \multicolumn{3}{|c|}{ Giza 21} \\
\hline$\overline{\mathbf{N}}$ & MW & $T$ & 2 & 3 & 1 & 2 & 3 & 1 & 2 & 3 & 1 & 2 & 3 & 1 & 2 & 3 \\
\hline 1 & 305 & 1 & 1 & 1 & 1 & 1 & 1 & 1 & 1 & 1 & 1 & 1 & 1 & 1 & 1 & 1 \\
\hline 2 & 144 & 1 & 1 & 1 & 1 & 1 & 1 & 1 & 1 & 1 & 0 & 0 & 0 & 1 & 1 & 1 \\
\hline 3 & 90 & 1 & 1 & 1 & 1 & 1 & 1 & 1 & 1 & 1 & 1 & 1 & 1 & 1 & 1 & 1 \\
\hline 4 & 87 & 1 & 1 & 1 & 1 & 1 & 1 & 1 & 1 & 1 & 1 & 1 & 1 & 1 & 1 & 1 \\
\hline 5 & 78 & 1 & 1 & 1 & 1 & 1 & 1 & 0 & 0 & 0 & 1 & 1 & 1 & 1 & 1 & 1 \\
\hline 6 & 56 & 1 & 1 & 1 & 1 & 1 & 1 & 1 & 1 & 1 & 1 & 1 & 1 & 1 & 1 & 1 \\
\hline 7 & 40 & 1 & 1 & 1 & 1 & 1 & 1 & 1 & 1 & 1 & 1 & 1 & 1 & 1 & 1 & 1 \\
\hline 8 & 30 & 0 & 0 & 0 & 0 & 0 & 0 & 1 & 1 & 1 & 0 & 0 & 0 & 0 & 0 & 0 \\
\hline 9 & 20 & 1 & 1 & 1 & 0 & 0 & 0 & 0 & 0 & 0 & 0 & 0 & 0 & 0 & 0 & 0 \\
\hline 10 & 15 & 1 & 1 & 1 & 1 & 1 & 1 & 1 & 1 & 1 & 1 & 1 & 1 & 1 & 1 & 1 \\
\hline
\end{tabular}


among ninety-two accessions of Glycine max. From these results, the number of bands of soybean seed protein patterns are ranged from 22 to 26 bands and protein profile can be used as a general biochemical fingerprint for the soybean (Barakat, 2004). Three of the studied cultivars (Giza22, Giza 35 and Giza 83) are distinguished by cultivar specific bands. The unique markers may help in identifying these cultivars. Also, these three cultivars are different in the weights of 100 seeds and having different pedigrees at least in one parent (Table 1). Some soybean cultivars were identified by biochemical genetic markers (Abdel-Tawab et al. 1993; Fahmy and Salama, 2002). Many investigators used seed storage protein to study genetic diversity; Ahmad et al. (1997), Badr et al. (2000) in the genous Lathyrus, Mustafa and El-Kholy 2008, among accessions of Vicia faba and Radwan et al. (2013) among accessions of Lathyrus inconspicuous. Many studies used SDS-PAGE for distinguishing cultivars and at infra specific levels (Signor et al., 2005; Sammour et al., 2007 a, b; Mustafa and ElKholy, 2008).

However, these protein profiles could be used as a general biochemical fingerprint for the soybean. The low level of protein polymorphism could be attributed to the conservative nature of seed proteins. (Bonfitto et al., 1999). Low level of protein polymorphism was also reported in mung bean cultivars (Hassan, 2001a). However many investigators have used seed storage protein variability for the identification and characterization of species and cultivars (Abdelsalam et al., 1998; Badr et al., 2000; Ibrahim, 2003).

\section{RAPD-PCR Analysis}

The RAPD fingerprinting by the four primers generated 31 bands (Fig. 3) with 70.96\% polymorphism. Both primers 3 and 4 generated more than $70 \%$ polymorphism (Table 3 ). From a total of 31 bands, 7 bands are unique to 3 cultivars from the 5 studied cultivars and 9 bands are monomorphic. Primer 3 produced a total of 11 bands comprised 3 bands common among the five soybean cultivars. Besides the high polymorphic bands detected by both primers 3 and 4 , there are positive and negative unique bands to be specific for some cultivars.
Three positive bands are unique to cultivar Giza 21 with molecular sizes of about $1651 \mathrm{bp}, 1560$ and $1272 \mathrm{bp}$, one positive unique band specific to Giza 111 at approximately molecular size $1163 \mathrm{bp}$ and 3 postive bands are unique to cultivar Giza 35 by all primers (Fig. 3 and Table 3 ). However, for the negative unique bands, one negative unique band specific to Giza 111 and Crawford was observed at approximately molecular size of 691 and 448, bp respectively. The maximum number of total RAPD bands (11 bands) was produced by primers 3 with five positive bands $(1560,1163,727,561$ and 505 bp) in cultivars Giza 21, Giza 35 and Giza 111 and one negative band with a molecular size of about 448 bp unique to cultivar Crawford.

RAPD amplification profile revealed $70.96 \%$ polymorphism among the studied soybean cultivars using the four primers and more than $70 \%$ polymorphism using 3 and 4 primers. Various combination of the three decamer oligonucleotides (primer 1 , primer 2 and primer 3) had been used in PCR run to increase the potential of the PCR reaction. The combination of the three primers gave high polymorphism percentage $(93.75 \%)$ than the single three primers (65.21\%) (Fig. 4 and Table 4). Mansour et al. (2008), found that various combination of three decamer oligonucleotides tended to increase the potential of the PCR reaction and the polymorphism in some Mango cultivars.

This relatively high polymorphism has been observed in many studies of genetic diversity on soybean cultivars (Abdel Noor et al., 1995; Mienie et al., 1995; Thompson and Nelson, 1998; Thompson et al., 1998; Chowdhery et al., 2001; Baranek et al., 2002; Tu et al., 2003; Barakat, 2004) reported that there was a low degree of RAPD polymorphism (46\%) among 19 soybean accessions included in the Czech National Collection of Soybean Genotypes.

Amplified RAPD fragments were differentiated among the studied cultivars and characterized by presence or absence of unique cultivar specific bands. Cultivar Crawford is distinguished by one negative band. Giza 111 one positive band and one negative band, Giza 35 (three positive bands) and Giza 21 (three positive bands) are also distinguished by cultivar specific bands. The RAPD markers are being successful to distinguish 
Zagazig J. Agric. Res., Vol. 44 No. (3) 2017

Primer CS- 44

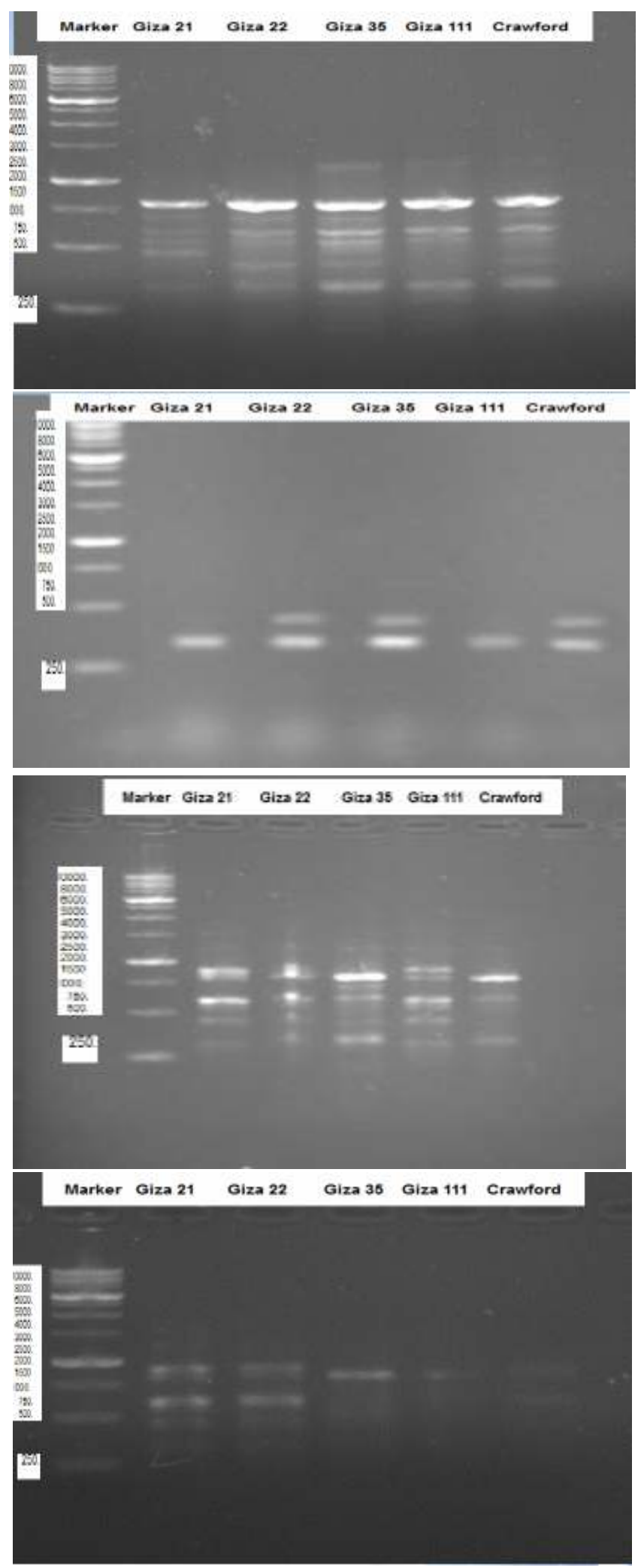

Fig. 3. DNA polymorphism of the five soybean genotypes using four random primers 
Table 3. Number of amplification, polymorphic, monomorphic products and percentage of polymorphism generated by four random primers used for identifying five cultivars of soybean (Glycine max L.)

\begin{tabular}{|c|c|c|c|c|c|c|c|c|c|c|}
\hline Primer & $\begin{array}{c}\text { Range of } \\
\text { fragment size }\end{array}$ & $\begin{array}{c}\text { Giza } \\
21\end{array}$ & $\begin{array}{c}\text { Giza } \\
22\end{array}$ & $\begin{array}{c}\text { Giza } \\
35\end{array}$ & $\begin{array}{l}\text { Giza C } \\
111\end{array}$ & Crawford & $\begin{array}{c}\text { Total No. } \\
\text { of fragments }\end{array}$ & $\begin{array}{l}\text { Monomorphic } \\
\text { Fragments }\end{array}$ & $\begin{array}{l}\text { Polymorphic } \\
\text { Fragments }\end{array}$ & $\begin{array}{c}\text { Polymorphism } \\
(\%)\end{array}$ \\
\hline 1 & $333-426$ bp & 1 & 2 & 2 & 1 & 2 & 2 & $\overline{1}$ & 1 & $50 \%$ \\
\hline 2 & 250-1211 bp & 6 & 6 & 10 & 7 & 8 & 10 & 4 & 6 & $60 \%$ \\
\hline 3 & 324-1560 bp & 6 & 5 & 8 & 6 & 4 & 11 & 3 & 8 & $72.72 \%$ \\
\hline 4 & 309-1651 bp & 7 & 5 & 3 & 2 & 3 & 8 & 1 & 7 & $87.5 \%$ \\
\hline Total & 250-1651 bp & 20 & 18 & 23 & 16 & 17 & 31 & 9 & 22 & $70.96 \%$ \\
\hline Average & & 5 & 4.5 & 5.75 & 4 & 4.25 & 7.75 & 2.25 & 5.5 & \\
\hline
\end{tabular}

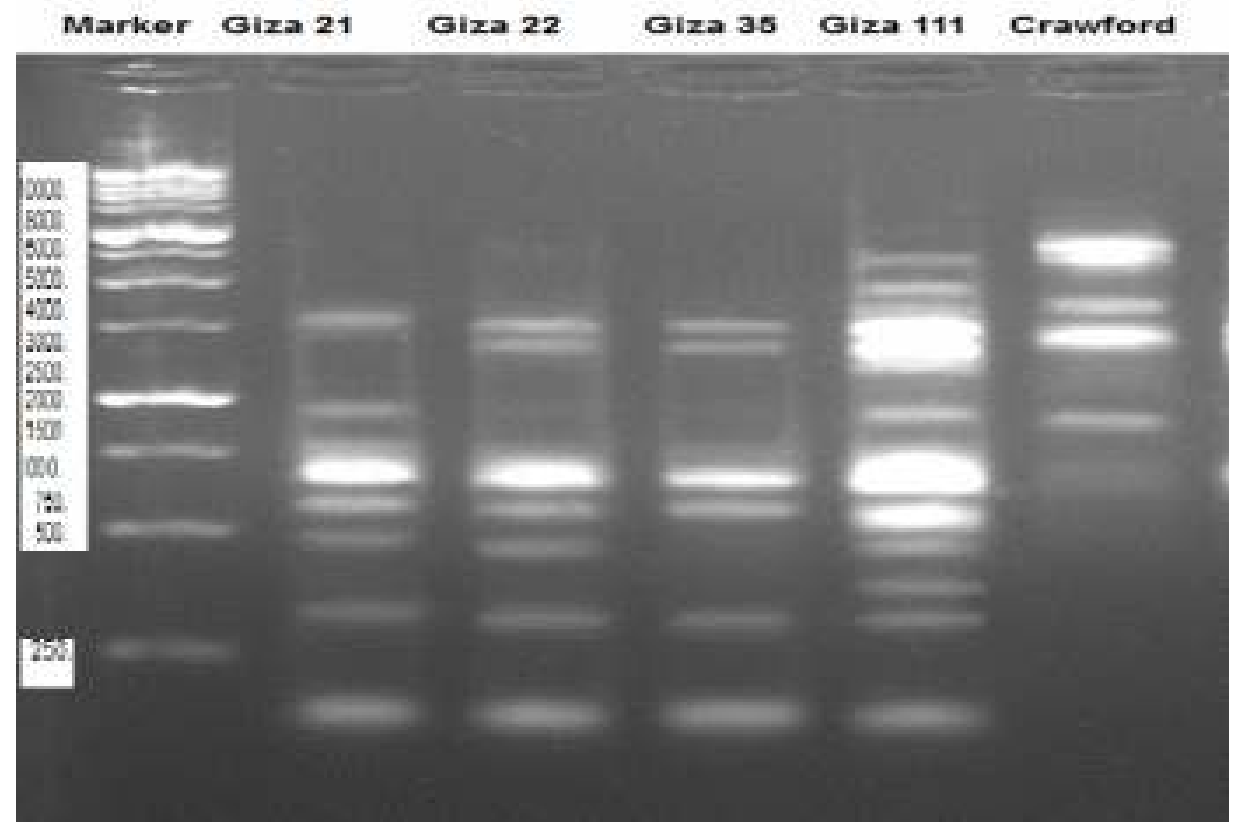

Fig. 4. DNA polymorphism of five soybean genotypes using triple RAPD-PCR

Table 4. Comparison between RAPD results using three separately primers $(1,2,3)$ and Triple RAPD PCR $(1,2,3)$ products using the same primers

\begin{tabular}{cccccccccccc}
\hline Primer & $\begin{array}{c}\text { Range of } \\
\text { fragment size }\end{array}$ & $\mathbf{2 1}$ & $\mathbf{2 2}$ & $\mathbf{3 5}$ & $\mathbf{1 1 1}$ & & Fragments & Fragments & Fragments & (\%) \\
\hline $\mathbf{1}$ & $\mathbf{3 3 3 - 4 2 6}$ bp & 1 & 2 & 2 & 1 & 2 & 2 & 1 & 1 & $50 \%$ \\
$\mathbf{2}$ & $\mathbf{2 5 0 - 1 2 1 1}$ bp & 6 & 6 & 10 & 7 & 8 & 10 & 4 & 6 & $60 \%$ \\
$\mathbf{3}$ & $\mathbf{3 2 4 - 1 5 6 0}$ bp & 6 & 5 & 8 & 6 & 4 & 11 & 3 & 8 & $72.72 \%$ \\
Total & $\mathbf{2 5 0 - 1 5 6 0}$ bp & 13 & 13 & 20 & 14 & 14 & 23 & 8 & 15 & 65.21 \\
$\mathbf{1 , 2 , 3}$ & $\mathbf{1 6 9 - 5 5 7 8}$ bp & 8 & 8 & 8 & 13 & 6 & 16 & 1 & 15 & 93.75 \\
\hline
\end{tabular}


these four cultivars from other studied cultivars. These results are in agreement with those obtained by Barakat (2004) who reported that RAPD markers can successfully be used to produce variety specific fingerprints in soybean. Mienie et al. (1995) suggested that RAPD markers can be used for identification in South African soybean cultivars. RAPD marker is a valuable tool for assessing genetic diversity levels in 47-East Asian vegetable soybean varieties and showed high level when compared to other morphological markers (Chowdhery et al., 2001). However, Weian et al. (2009) suggested that AFLP and SSR are more suitable than RAPD for genetic diversity studies in soy bean. SSR markers are efficient to differentiate between wild soybeans, cultivars and varieties (Tantasawat et al., 2011).

RAPD-PCR markers have been used in different plants to assess variations. Badr et al. (2012) reported the analysis of morphological variations and RAPD polymorphism distinguished among populations of Artenesia in Central and North Saudi Arabia.

\section{Cluster Analysis}

The cluster analysis classified the studied cultivars into three groups (Table 5 and Fig. 5). The first group included Giza 22, Crawford and Giza35, while the second and third groups included Giza21 and Giza 111, respectively, where each cultivar was in separate group. The two cultivars; Giza22 and Giza35 are clustered in one group with Crawford as the pedigree information showed that Crawford is a common parent for them. The highest similarity coefficient between Giza22 and Crawford (0.792) and the dendrograms indicate that these two cultivars are closely related. The lowest similarity coefficients are recorded between cultivar Giza35 and Giza111 (0.636) although their parents are the same. As well Crawford and Giza 111 present lowest similarity coefficients (0.636) although Crawford is a parent of Giza 111.

The genetic relationship among barley cultivars (El-Shazly and El-Metairi, 2006) and turf grass (Al-Khalifa et al., 2005) were determined by RAPD markers. RAPD analysis was also used for the characterization and grouping of wheat genotypes (Bhutta et al., 2006).

The identification of cultivars with maximum genetic divergence should optimize the choice of progenitors for crosses having specific objectives such as plant breeding or the construction of genetic maps. The genetic relationship between the studied cultivars based on combination of protein and RAPD have been estimated. The seed storage proteins revealed variations among the five soybean cultivars as well RAPD-PCR showed high polymorphism and discriminated between them. Two primers (Primer CS- 56, Primer OH- 04) from the four primers revealed high degree of polymorphism among studied cultivars. The genetic relationships among some soybean cultivars in this study agree with pedigree information and others disagree. This is consistent with Abdelnoor et al. (1995) who reported that RAPD data of soybean cultivars were coherent for most pedigree data while Doldi et al. (2006) reported that the dendrogram derived from RAPD data showed some divergence from the pedigree information available for soybean lines.

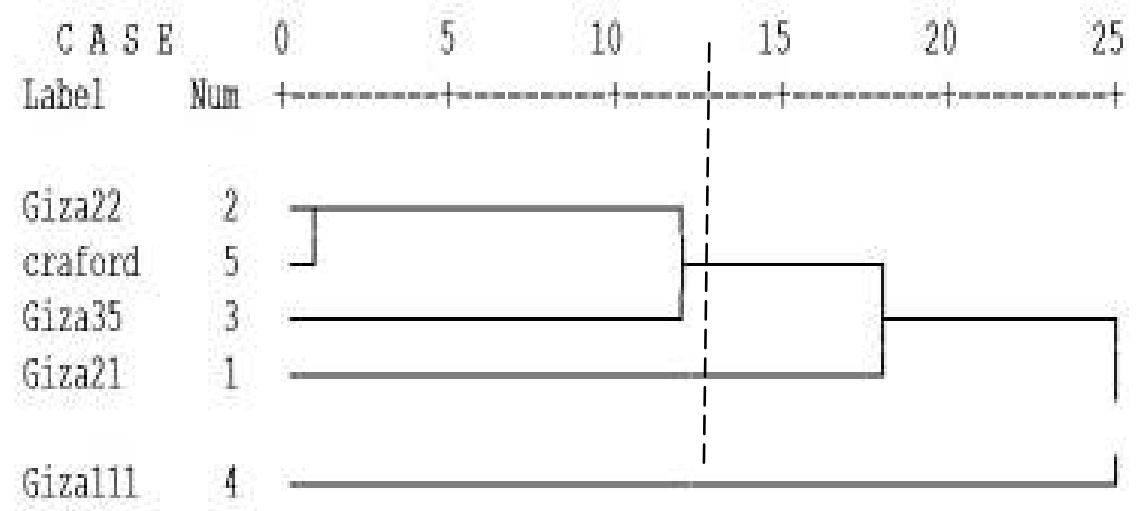

Fig. 5. Dendrogram using average linkage distance between soybean cultivars based on the combined analysis of storage protein and RAPD Profile 
Adbel Hamid, et al.

Table 5. Similarity coefficients among the five soybean cultivars estimated by seed protein and RAPD analysis

\begin{tabular}{lccccc}
\hline Cultivar & Giza 21 & Giza 22 & Giza 35 & Giza 111 & Crawford \\
\hline Giza 21 & 1.000 & & & & \\
Giza 22 & 0.753 & 1.000 & & & \\
Giza 35 & 0.649 & 0.740 & 1.000 & & \\
Giza 111 & 0.649 & 0.688 & 0.636 & 1.000 & \\
Craw ford & 0.675 & 0.792 & 0.714 & 0.636 & 1.000 \\
\hline
\end{tabular}

\section{REFERENCES}

Abdel Noor, R.V., E.G. Barros and M.A. Moreira (1995). Determination of genetic diversity within Brazilian soybean germplasm using random amplified polymorphic DNA techniques and comparative analysis with pedigree data. Rev. Brazil. Genet., 18 (2): 265.

Abdelsalam, A.Z.E., S.A. Ibrahim, F.M. Eldomyati and G.H. El-Nady (1998). Biochemical and molecular $3^{\text {rd }}$ Arab Conf. Modern Biotech. And Areas of Application in the Arab World, Cairo, Egypt, 582-605.

Abdel-Tawab, F.M., M.A. Rashed, E.M. Fahmy and F.M. Eldomyati (1993). Soyabean cultivar identification by biochemical genetic markers. In: $4^{\text {th }}$ Conf. Agric. Dev. Res., Ain Shams Univ., Cairo, Feb.13-18 Ann. Agric. Sci., Sp. Issue, 2: 455-63.

Ahmad, M., A.G. Foutrier, D.J. Burritt and D.L McNeil (1997). Genetic diversity and relationships in Lens species and their F1 interspecific hybrids as determined by SDSPAGE. Newzealand J. Crop Hort. Sci., 25 99.

Al-Khalifa, N.S., E. Askari, A.E. Shanavaskhan and S. Hadi (2005). Morphologic and genetic analysis of some turf grass cultivars grown in Saudi Arabia. Proc. 10 $0^{\text {th }}$ Turf Grass Res. Conf., Wales, United Kingdom, 54.

Aly, M.A., N.A.K. Rashed and H.Z. Hassan (2000). Genetic variability and assessment of relationships among some Egyptian rice (Oryza sativa L.) cultivars as revealed by
SDS-protein and PCR-RAPD analyses. Egypt J. Gent. Cytol., 29: 71-87.

Badr, A., H.H. El-Shazly and M. Abou E-Enain (2000). Seed protein diversity and its implications on the relationships in the genus Lathyrus L. (fabaceae). In: Proc. $1^{\text {st }}$ Conf. Biol. (ICBS), 7-8 May. Fac. Sci., Tanta Univ., Egypt, 333-46.

Badr, A. (2008). Molecular approaches to plant systematic and evolution. In: Proceedings of Egyptian-Swedish Symposium commemorating. ViviTaeckholm's $110^{\text {th }}$ Birthday, 28, Cairo Univ., Egypt, 127.

Badr, A., H. El-Shazly, N.S. Helail and W. El Ghanim (2012). Genetic diversity of Artemisia populations in Central and North Saudi Arabia based on morphological variation and RAPD polymorphism., 298 : 871.

Barakat, H. (2004). Genetic fingerprinting and relationships of six soybean (Glycine max L.) cultivars based on protein and DNA Polymorphism. Int. J. Agric. Biol., 6 (5): 877.

Baránek, M., M. Kadlec, J. Raddová, M. Vachůn and M. Pidra (2002). Evaluation of genetic diversity in 19 Glycine $\max$ (L.) Merr. accessions included in the Czech national collection of soybean genotypes. Czech J. Genet. Plant Breed., 38 (2): 69.

Barua, U.M., K.J. Chalmers, C.A. Hackett, W.T.B. Thomas, W. Powell and R. Waugh (1993). Identification of RAPD markers linked to a Rhynchosporium secalis resistance locus in barley using near-isogenic 
lines and bulked segregant analysis. Heredity, 71: 177.

Bhutta, W.M., J. Akhtar, M. Ibrahim and A. Shahzad (2006). Genetic variation between Pakistani wheat (Triticum aestivum L.) genotypes as revealed by random amplified polymorphism DNA (RAPD) markers. South Afr. J. Bot., 72 (2), 280.

Bonfitto, R., L. Galleschi, M. Macchia, F. Saviozzi and F. Navari-Izzo (1999). Identification of melon cultivars by gel and capillaryelectrophoresis. Seed Sci. Tech., 27: $779-83$

Chowdhery, A.K., P. Srinives, P. Tongpmnak and P. Saksoong (2001). Genetic diversity based on morphology and RAPD analysis in vegetable soybean. Korea J. Crop Sci., 46 (2): 112 .

Doldi, M.L., J. Volimann and T. Lelley (2006). Genetic diversity in soybean as determined by RAPD and microsatellite analysis. Plant Breed., 116 (4): 331.

El-Shazly, H.H. and Z. El-Metairi (2006). Genetic relationships of some barley cultivars, based on morphological criteria and RAPD finger-printing. Int. J. Bot., 2, 252.

Fahmy K.H. and S.I. Salama (2002). Biochemical and genetic finger. prints for some soybean [Glycine $\max$ (L.) Merr.] cultivars resistant to Etiella zinekenlla (Triet.) Egypt. J. Genet., 31: 309-29.

Gardiner, S.E. and M.B. Forde (1988). Identification of cultivars and species of pasture legumes by sodium dodecylsulphate polyacrylamide gel electrophoresis of seed protein. Plant Varieties and Seeds, 1: 13.

Gorman, M.B. (1988). Electrophoretic estimates of genetic diversity in soybeans. Genome, 30: 4-6.

Hassan, H.Z. (2001a). Biochemical and molecular genetic characterization of nine mung bean (Vigna radiate L.) cultivars. Bull. Fac. Assiut Univ., 30: 137-51.

Hassan, H.Z. (2001b). Genetic fingerprinting and relationships of some lentil (Lens esculenta Moench) cultivars based on protein and DNA polymorphism. In: The $8^{\text {th }}$ Int. Conf., 4-7 November. Arab Biologists, Faculty of Sci., Fayuom Univ., Egypt, 11-31.

Hoque, M.E. and M.M. Hasan (2012) Molecular diversity analysis of lentil (Lens culinaris Medik.) through RAPD markers. Plant Tissue Cult. and Biotech., 22 (1): 51.

Hsieh, J.S., K.L. Hsieh, Y.C. Tsai and Y.I. Hsingl (2001). Each species of Glycine collected in Taiwan has a unique seed protein pattern. Euphytica, 118: 67-73.

Ibrahim, S.M. (2003). Biochemical and molecular genetic fingerprints of some Cruciferae plants. M.Sc. Thesis, Fac. of Education, Ain Shams Univ., Cairo, Egypt Jhy-Jhu, LIN, K. Jonathan,

Klein-Lank, H.R.M., A. Vermunt, R. Weide, T. Liharska and P. Zabel (1991). Isolation of molecular markers for tomato (L. esculentum) using random amplified polymorphic DNA (RAPD). Theoretical and Appl. Genet., 83: 108-14.

Kour, A. and S.P. Singh (2004) Evaluation of genetic diversity in different genotypes of Brassica juncea by SDS-PAGE. New directions for a diverse planet: Proceedings of the $4^{\text {th }}$ Int. Crop Sci. Cong., Brisbane, Aust., 26, 1.

Laemmeli, U.K. (1970). Cleavage of structural proteins during assembly of head bacteriophage T4. Nature, 227: 680-5.

Larsen, A.L. (1967). Electrophoretic differences in seed proteins among varieties of soybean Glycine max (L.) Merrill., Crop Sci., 7: 3113.

Lin, K.H., Y.C. Lai, H.C. Li, S.F. Lo, L.F.O. Chin and H.F. Lo (2009). Genetic variation and its relationship to root weight in the sweet potato as revealed by RAPD analysis. Sci. Hort., 120 (1): 2.

Liu, F., B.C. Zhuang, J.S. Zhang and S.Y. Chen (2000). Construction and analysis of soybean genetic map. Yi Chuan Xue Bao., 27 : 1018 1025.

Lowry, K.L., J.E. Carton and D.E. Foard (1974). Electrophoretic methods for detecting differences in seed protein of soybean 
varieties and induced mutants. J. Agri. Food Chem., 22: 1043 - 1055.

Malik, M.F.A., A.S. Qureshi, M. Ashraf, M.R. Khan and A. Javed (2009). Evaluation of genetic diversity in soybean (Glycine max) lines using seed protein electrophoresis. Aust. J. Crop Sci., 3 (2): 1007 - 1017.

Mansour, A., O.M. Ismail and S.M. Mohei ElDin (2008). Diversity assessments among Mango (Mangifera indica L.) cultivars in Egypt using ISSRs and three-primer based RAPD fingerprints. Afr. J. Plant Sci. and Biotechnol., 2 (2): 87-92.

Mienie, C.M.S., M.A. Smit and P.J. Pretonus (1995). Use of random amplified polymorphic DNA for identification of South African soybean cultivars. Field Crops Res., $43: 43$.

Mori, T., S. Utsumi, H. Inada, K. Kitamura and K. Harada (1981). Differences in subunit composition of glycine among soybean cultivars. J. Agric. Food Chem., 29: 20-30.

Mustafa, A.M.A. and A.S. El-kholy (2008). Genetic diversity among some accessions of Vicia faba L. around the world. Proc. $5^{\text {th }}$ Int. Con. Biol. Sci. (Botany), 5 - 10.

Prasanthi, L., B. Geetha, R.B.N. Jyothi and K. Reddy (2012). Evaluation of genetic diversity in cowpea, Vigna unguiculata (L.) Walp genotypes using random amplified polymorphic DNA (RAPD). Current Biotica, 6 (1): 22.

Radwan, S.A., A.S. El-Koly and R.H. Sammour (2013). Genetic variation among accessions of Lathyrus inconspicuous (L.) as revealed by SDS polyacrylamide gel Electrophoresis. Acta Agric. Slovenica, 101 (1): 21.

Rashed, M.A., E.M. Fahmy, M.T.M. Sharabash, A.H. Hammad and H.M. El-Demerdash (1997). Biochemical genetic markers for discriminating high yielding soybean plants (Glycine max L.) after irradiation with gamma rays. J. Agric. Sci., Ain Shams Univ., Egypt, 5: 69-87

Rohlf, F.J. (1993). NTsys-pc, Numerical Taxonomy and Multivariate Analysis System. Exeter software, New York.
Saio, K.M.K. and T. Watanabe (1969). Food processing characteristics of soybean $11 \mathrm{~S}$ and $7 \mathrm{~S}$ proteins. Part I. Effect of difference of protein components among soybean varieties on formation of tofu gel Agric. and Biol. Chem., 33: 1301-1308

Sammour, R., A. Mustafa, S. Badr and W. Taher (2007a). Genetic variations in accessions of Lathyrus sativus L. Acta Bot. Croat., 66 (1): 1.

Sammour, R.H., S.A. Radwan and A. El-Kholy (2007b) Genetic variability in Phaseolus spp. as revealed by SDS-PAGE markers. Seed Technol., 29: 50.

Signor, C.L., K. Gallardo, J.M. Prosperi, C. Salon, L. Quillien, R. Thompson and G. Duc (2005). Genetic diversity for seed protein composition in Medicago truncatula. Plant Genet. Res., 3 (1): 59.

Stejskal, J. and M. Griga (1995). Comparative analysis of some isozymes and proteins in somatic and zygotic embryos of soybean [Glycine $\max$ (L.) Merr.] J. Plant Physiol., 146: 497-502.

Tantasawat, P., J. Trongchuen, T. Prajongjai, S. Jenweerawat and W. Chaowiset (2011). SSR analysis of soybean (Glycine max (L.) Merr.) genetic relationship and variety identification in Thailand. Aust. J. Crop Sci. AJCS, 5 (3): 283.

Thompson, J.A., R.L. Nelson and L.O. Vodkin (1998). Identification of diverse soybean germplasm using RAPD markers. Crop. Sci., 38: 1348.

Thompson, J.A. and R.L. Nelson (1998). Core set of primers to evaluate genetic diversity in soybean. Crop Sci., 38 : 1356.

Tu, P.T.B., N.T. Lang and B.C. Buu (2003). Soybean genetic diversity analysis. Omonrice, 11: 138.

Weian, Z.H., Y. Wang, Q. Li, B. Zhuang, L. Gong and L. Bao (2009). Genetic diversity in annual wild soybean (Glycine soja sieb. et zucc.) and cultivated soybean (G. max.merr.) from different latitudes in china. Pak. J. Bot., 41 (5): 2229. 
Williams, J.G.K., A.R. Kubelik, K.J. Livak, J.A. Rafalski and S.V. Tingey (1990). DNA polymorphism amplified by arbitrary primers are usefulas genetic markers. Nucl. Acid Res., 18: 6531-5

Witkus, R., J. Deobley and F. Wendel (1994). Nuclear DNA Markers in Systematics and Evolution. DNA Based Markers in Plants
Philips, R.L. and Vasil, J. K. (eds.). Kulwer Academic Publ., Dordrecht. The Netherlands, 116.

Yaklich, R.W., B. Vinyard, M. Cap and S. Douglass (2002). Analysis of seed protein and oil from soybean northem and southern region uniform tests. Crop Sci., 42 : 1504-15.

\section{تعيين التنوع الوراثي لبعض أصناف فول الصويا باستخذام طرز بروتينات البذور المختزنة وتحليل

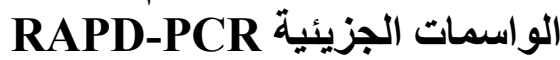

$$
\begin{aligned}
& \text { محمد عبد السلام عبد الحميد ـ عبد الرحمن السيد مندور } \\
& \text { طارق أبو المحاسن إسماعيل ـ أحمد منصور الزهير الزيري }
\end{aligned}
$$

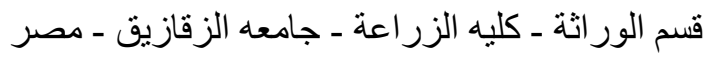

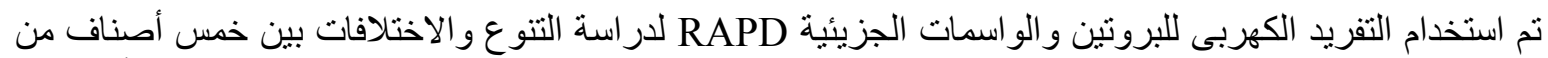

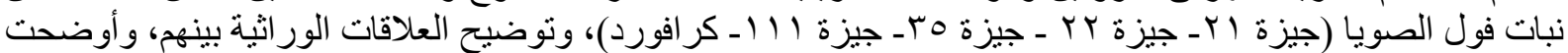

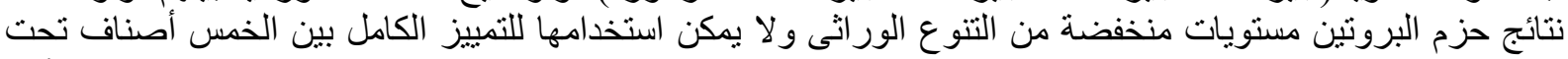

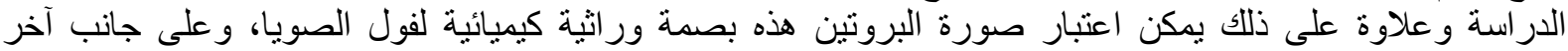

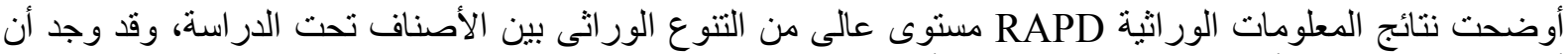

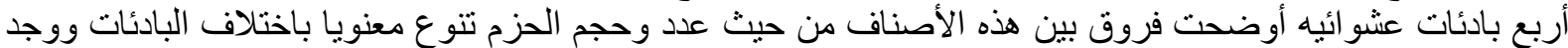

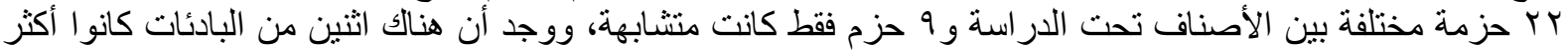

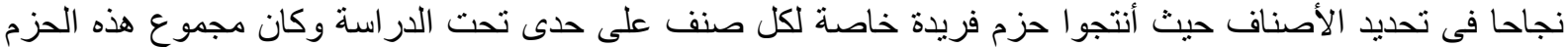

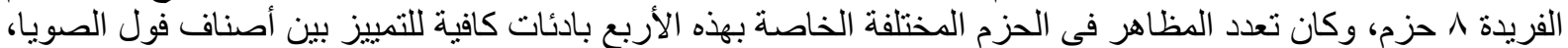

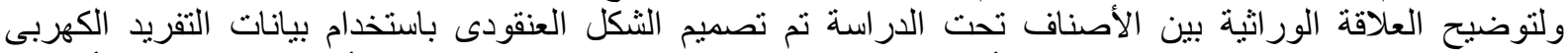

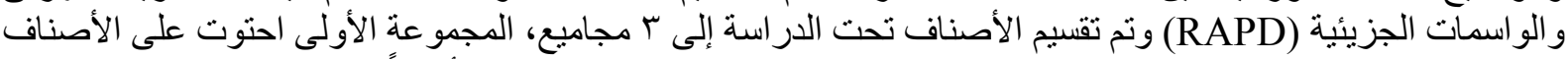

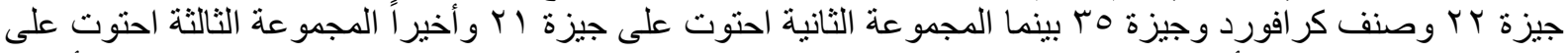

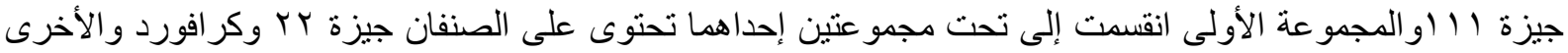

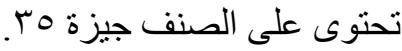

أستاذ الور اثة ـ كلية الزر اعة - جامعة عين شمس.

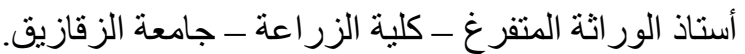

